\title{
Izabela Chudzyńska
}

Wyższa Szkoła Gospodarki w Bydgoszczy

Katedra Gospodarki Turystycznej

izabela.chudzynska@byd.pl

(D) https://orcid.org/0000-0001-5123-6329

\section{Kuchnia ochweśnicka narzędziem promocji regionu}

\begin{abstract}
Zarys treści: Współczesne jedzenie nabrało nowego, szerszego wymiaru. To nie tylko sposób na zaspokojenie głodu, wyrażenie swojej pozycji społecznej czy określenie narodowej bądź regionalnej tożsamości, współczesne jedzenie to jedzenie świadome, sposób na ekspresję posiadanego światopoglądu, to część współczesnej etyki. Jedzenie to również doskonałe narzędzie do promocji miasta bądź regionu. Celem opracowania jest analiza zagadnień związanych z kuchnią regionalną na przykładzie kuchni ochweśnickiej jako narzędzia skutecznie promującego region. Metodę badawczą zastosowaną $\mathrm{w}$ niniejszym opracowaniu ściśle dopasowano do jego celów. Wykorzystano analizę danych zastanych, tzw. desk research, w tym pięć strategii propagowania etnicznych/lokalnych kuchni opracowanych przez Long (2015). Wykazano, że badana kuchnia chociaż ma wszystkie cechy „nowego” jedzenia, opisane przez Lucy Long, które wywołują zainteresowanie konsumentów, nie stała się skutecznym narzędziem promującym region.
\end{abstract}

Słowa kluczowe: turystyka kulinarna, dziedzictwo kulinarne, strategia rozwoju regionu, kuchnia ochweśnicka

\section{Wprowadzenie}

W rolniczy krajobraz okolic Skulska i Ślesina wkomponowane jest sanktuarium maryjne w Licheniu Starym. Od wielu lat progi tej świątyni przestępują tysiące pielgrzymów. To dzięki nim wielu Polakom udaje się umiejscowić na mapie gminę Ślesin (sąsiadująca gmina Skulsk pozostaje nadal nierozpoznawalna). Tereny obu gmin cechuje rolniczy krajobraz typowy dla Wielkopolski, poprzetykany malowniczymi jeziorami, na których można uprawiać turystykę wodną. Obszar ten udostępnia doskonałe warunki do żeglarstwa, kajakarstwa, wioślarstwa, windsurfingu oraz sportów motorowodnych. Jeziora tych gmin wchodzą w skład szlaku wodnego, zwanego Wielką Pętlą Wielkopolski (długość 688 km). Nie tylko jeziora stanowią atrakcję tego obszaru, są nią również pamiątki przeszłości. W Ślesinie znajduje się Brama Napoleońska, którą w powszechnej opinii 
postawili w 1812 r. mieszkańcy miasteczka na cześć francuskiego cesarza Napoleona Bonapartego. Za jej pośrednictwem mieli uniknąć zbyt dużych świadczeń na rzecz wojska. Inne źródła sugerują, że brama została zbudowana na cześć Fryderyka Augusta I Wettyna, który w latach 1807-1815 był księciem warszawskim (Budzińska i in. 2013). Fundatorem jej miał być właściciel miasta i jednocześnie dziedzic z pobliskiej miejscowości Piotrkowice - Walknowski (Walichnowski) herbu Wieruszowa. Taką wersję podaje dziedziczka mikorzyńska, Anna Milewska, w opublikowanym artykule z 1880 r. w czasopiśmie „Wędrowiec”. Orzeł, który znajduje się na szczycie bramy, nie tylko nie wyjaśnia powodów jej powstania, ale dodatkowo budzi liczne spory. Najczęściej uznaje się go za orła napoleońskiego. Pomimo to część heraldyków widzi w nim orła pruskiego, co może świadczyć o tym, że łuk triumfalny postawiono jednak, by uczcić cesarza pruskiego (http://gminaslesin.futurehost.pl). Natomiast w gminie Skulsk znajduje się pochodzący z połowy XIX w. pałac w Lisewie, obecnie zaadaptowany na kompleks restauracyjno-pałacowy (https://pl.wikipedia.org). Jeziora, zabytki i konieczność znalezienia innych źródeł zarobkowania niż rolnictwo spowodowały, że na tych terenach zaczęła rozwijać się turystyka. Jedną z inicjatyw lokalnych mających na celu uatrakcyjnienie regionu było odtworzenie kultury handlarzy gęsi. W centrum Ślesina usytuowano fontannę z gęsią i pomnik handlarza $z$ gęsią pod pazuchą. Na tablicy informacyjnej nieopodal pomnika zamieszczono informacje: „Gdy w 1358 roku Ślesin otrzymał prawa miejskie, czyli w praktyce prawo do organizowania targów, handel był już najważniejszym źródłem dochodów jego mieszkańców. Z czasem głównym przedmiotem handlu stały się gęsi. W ogromnych stadach, gęsi były pędzone na sprzedaż, nawet przez setki kilometrów. Handel odegrał także wielką rolę w kształtowaniu zwyczajów oraz wyjątkowego języka, którym ślesińscy kupcy posługiwali się w swej codziennej pracy. Gęsi i język do dziś pozostały symbolem handlowych tradycji tego miasta" (https://kieruneknadzis.blogspot.com). W programie gminnych imprez pojawiły się wydarzenia promujące kuchnie handlarzy gęśmi, tzw. kuchnię ochweśnicką, a restauracje w swoich menu zaczęły umieszczać jej dania. Starano się w ten sposób wykorzystać aktualny trend, polegający na budowaniu atrakcyjności turystycznej regionu na fundamentach dziedzictwa kulinarnego (Durydiwka 2013, s. 12), w ten sposób chciano umożliwić turystom degustację potraw kuchni regionalnej, kupowanie produktów naturalnych i uczestnictwo w kulinarnych warsztatach.

Celem opracowania jest analiza zagadnień związanych z kuchnią regionalną, na przykładzie kuchni ochweśnickiej, jako narzędzia skutecznie promującego region. Do tego celu odpowiednio dobrano metodę badawczą. Zastosowano analizę danych zastanych, tzw. desk research, do której wykorzystano także pięć strategii propagowania etnicznych/lokalnych kuchni opracowanych przez Long (2015).

\section{Czym jest kuchnia ochweśnicka?}

W wyniku drugiego rozbioru Polski Ślesin znalazł się $\mathrm{W}$ zaborze pruskim. W 1815 r., po kongresie wiedeńskim, który po epoce napoleońskiej starał się 
przywrócić dawny ład w Europie, Ślesin znalazł się w Królestwie Polskim, czyli w zaborze rosyjskim. W niedalekim Anastazewie i Strzałkowie przebiegała granica z zaborem pruskim, co sprzyjało rozwojowi przygranicznego handlu. W XVIII w. głównym towarem wędrownych kupców okolic Slesina i Skulska były ochwesty, czyli ręcznie malowane obrazy świętych. Handlarze dla utajnienia swoich rozmów zaczęli porozumiewać się między sobą „tajemnym językiem”, później nazwanym kminą ochweśnicką, którą stanowił zlepek słów zapożyczonych z różnych języków: polskiego, rosyjskiego, niemieckiego i czeskiego. W XIX w. „język” ten przejęli ślesińscy handlarze gęśmi. Ochweśnicy zajmowali się przepędzaniem gęsi do komór celnych m.in. w Anastazewie i Strzałkowie, skąd gęsi koleją jechały w głąb Niemiec. Dojście do kolei wymagało przebycia wielu kilometrów, dlatego przed wyruszeniem w drogę gęsi były „podkuwane”. W celu zabezpieczenia gęsich łap przepędzano ptaki przez płynną smołę, a następnie pierze. Tak przygotowane gęsi mogły pokonać czekającą je długą drogę bez pokaleczenia łap (http://gminaslesin.futurehost.pl). Obecnie mało kto zajmuje się w gminie Ślesin i Skulsk hodowlą i handlem gęśmi, nieliczni znają też „kminę ochweśnicką”. Jeszcze do niedawna było osiem osób, które opanowały umiejętność posługiwania się tym „językiem” (http://idziemy.pl). Historia handlarzy drobiu stała się kanwą do stworzenia kuchni ochweśnickiej, której podstawowymi składnikami są gęsina i ziemniaki. Potrawy składające się na tę kuchnię zostały zaczerpnięte z oferty dań przygotowywanych przez członkinie Kół Gospodyń Wiejskich okolic Ślesina. Dlatego też wydaną przez Miejsko-Gminny Ośrodek Kultury w Ślesinie książkę z recepturami kuchni ochweśnickiej zatytułowano „Kuchnia wiejska”. Przepisy w niej zgromadzone opierają się na powszechnie dostępnych w wiejskich sklepach składnikach, z których według dyrektora ośrodka kultury i współautora książki kucharskiej można było z „niczego zrobić coś” (Augustyniak 2020, s. 27). Podstawowym składnikiem tej kuchni są ziemniaki, nazywane „pyrami” lub „kartoflami”. Daniami przygotowywanymi z nich są: obsypunka, prażuchy, kluski ziemniaczane, pyzy z ziemniaków surowych, pyrczok oraz plyndze, czyli placki ziemniaczane. Obsypunka to wypełnione masą ziemniaczaną jelita wieprzowe. Te ziemniaczane kiełbasy podawane są po ugotowaniu. Niekiedy dodatkowo są obsmażane lub grillowane. Prażuchy (zwane też dziadami) to porcje masy ziemniaczanej wymieszanej z pokrojonym boczkiem, które podaje się po obsmażeniu z przesmażoną cebulką. Natomiast pyrczok to rodzaj zapiekanki z surowych ziemniaków, mięsa wieprzowego, kiełbasy i boczku. Pyrczok nazywany jest też „bambrzokiem", w przeszłości nazwę tę stosowano do określania ludności niemieckiej (http://gminaslesin.futurehost.pl). Typowymi zupami kuchni ochweśnickiej są: polewka, czyli zupa z kwaśnego mleka, oraz czarnina, zwana "czarną polewką". W opinii gospodyń zrzeszonych w Kole Gospodyń Wiejskich w Ignacewie, tradycyjna czarnina powinna być serwowana $z$ kluskami ziemniaczanymi i „owijonkami”. "Owijonki” przygotowuje się z oczyszczonych jelit kaczych, za pomocą których przywiązuje się do kaczych łap żołądki (Boroński, Chmielewski br., s. 22-24). Potrawy $z$ gęsiny reprezentowane są przez gęsie pipki (to rodzaj gulaszu $z$ duszonych gęsich żołądków), gęś faszerowaną kaszą, gęś z ryżem i gruszkami, gęś cezara i gęś po chłopsku. W zbiorze spisanych tradycyjnych receptur okolic 
Ślesina znalazły się również przepisy na dania, które opatrzone zostały określeniem „ochweśnicka” lub „ochweśnicki”. Potrawami tymi są kapusta ochweśnicka i tort ochweśnicki (Boroński, Chmielewski br., s. 31, 54). Recepturę na tort ochweśnicki dostarczyły członkinie KGW Marianowo. Tort ten składa się z klasycznego biszkoptu i kremu grzanego russel ${ }^{1}$. Natomiast kapusta ochweśnicka to rodzaj zapiekanki składającej się z kapusty kiszonej, ryżu, mielonego mięsa i wędlin. Poszczególne składniki dania układa się warstwami i zapieka. Danie to jest od przeszło 20 lat atrakcją imprez grillowych Agroskansenu „Leśna Polana” położonego nad Jeziorem Ślesińskim. Potrawą lokalną, która swoją nazwą nawiązuje do miejsca, jest pstrąg po ślesińsku. Ryba przygotowywana zgodnie z tą recepturą faszerowana jest suszonymi śliwkami i pieczarkami przesmażonymi z cebulą.

Kuchnia ochweśnicka w roku 2013 była tematem przewodnim projektu pn. „Kuchnia ochweśnicka produktem markowym gminy Ślesin” realizowanym przez Lokalną Organizację Turystyczną „Marina”. Celem tego projektu było przybliżenie historii i tradycji kuchni ochweśnickiej osobom zamieszkującym gminę bądź na jej terenie pracującym, a związanym $z$ gastronomią. $W$ folderze wydanym w ramach projektu znalazła się krótka charakterystyka kuchni ochweśnickiej: „Oryginalna kuchnia ochweśnicka bazuje na prostych i łatwo dostępnych składnikach, z których można było stworzyć wysokoenergetyczne posiłki. Podstawowym elementem potraw kuchni ochweśnickiej są ziemniaki, w miarę możliwości okraszone mięsem lub cebulą. $\mathrm{Z}$ ziemniaków przygotowywano potrawy takie jak placki ziemniaczane, szare kluski okraszone skwarkami, szagówki (kluski z mąki i ziemniaków), pyry z gzikiem (czyli ziemniaki z serem) lub pyrczok. Na świątecznym stole znajdowały się często potrawy z drobiu, takie jak kurczak pieczony lub duszony, gęś pieczona czy gęsi pipek. Daniem typowo regionalnym jest też czarnina czyli zupa $z$ dodatkiem krwi kaczej. Wśród przypraw dominowały suszone i świeże zioła, popularnym dodatkiem były też grzyby, łatwo dostępne dzięki bliskości lasu" (http://docplayer.pl). Folder zawiera również adresy lokali gastronomicznych, w których serwowane są dania kuchni ochweśnickiej.

Mimo że wszystkie kolejne szczeble samorządu terytorialnego zaangażowały się w edukację kulinarną miejscowej ludności zatrudnionej w gastronomii oraz kobiet stowarzyszonych w Kołach Gospodyń Wiejskich, w publikowanie broszur i książek, a także organizowanie konkursów, festynów, w opinii osób bezpośrednio zajmujących się jej promocją kuchnia ochweśnicka nie stała się atrakcją przyciągającą turystów (Augustyniak 2020). Szukając wyjaśnienia przyczyn tego zjawiska, na podstawie dostępnych źródeł (drukowanych, internetowych) w dalszej części niniejszego opracowania poddano analizie potrawy składające się na lokalną kuchnię. Do tego celu wykorzystano opisane przez Long (2015) strategie popularyzowania etnicznych/lokalnych kuchni, aby przy ich udziale ustalić, jakie cechy kuchni ochweśnickiej sprawiają, że nie stała się ona skutecznym narzędziem promocji regionu.

Kremy grzane otrzymuje się z jaj, cukru, masła lub margaryny i substancji smakowo-zapachowych. Kremy należące do tej grupy sporządza się z ogrzanej masy jajowo-cukrowej, którą ubija się i łączy z napowietrzonym tłuszczem. 


\section{Język kuchni lokalnych}

Lokalne jedzenie może być powodem dumy, sposobem na wyróżnienie się od sąsiadów, jak również czynnikiem przyciągającym klientów w przypadku restauracji czy turystów w przypadku regionu/miasta. Lucy M. Long, analizując sposoby prezentowania etnicznych/lokalnych kuchni, wyróżniła pięć strategii ich propagowania. Jednym $z$ wybranych przez nią miejsc do prowadzenia obserwacji były koreańskie restauracje, ponieważ tam sukces przyjętych strategii przekładał się na wymierny efekt popularności lokali wśród klientów (Long 2015, s. 435-446). Pierwsza strategia negocjacji z konsumentem nowego jedzenia polega na zaznaczeniu jego „ram”, czyli wkomponowaniu jedzenia w charakterystyczną scenerię, $\mathrm{np}$. $\mathrm{w}$ postaci specyficznego języka $\mathrm{w}$ menu, odpowiednich dekoracji $\mathrm{w}$ miejscu spożywania jedzenia czy niecodziennej aranżacji potraw. Spośród lokali wymienionych $\mathrm{w}$ folderze promujących kuchnię ochweśnicką próbę wkomponowania oferty gastronomicznej w klimat dawnego Ślesina, którego uliczkami przechadzali się handlarze gęśmi, podjęto w Oberży Pod Kulawą Gęsia. Sama nazwa restauracji sugeruje związki z przeszłością ${ }^{2}$ poprzez zastosowanie słów oberża i gęś. Stylistykę odwołującą się do dawnych czasów wykorzystano też na stronie internetowej restauracji (http://www.oberzaslesin.pl). Kolorystyka jej nawiązuje do barw dawnych fotografii, które również zostały tam umieszczone. Stare zdjęcia handlarzy gęśmi tworzą główny filar wystroju restauracji. Wnętrze stanowi połączenie wielu stylów. Na ścianach znajdują się trofea myśliwskie, a bar jest pokryty strzechą. Ponownym nawiązaniem do gęsi jest informacja na stronie internetowej oberży, z której wynika, że w części hotelowej goście będą mieli do dyspozycji puchowe pierzyny wykonane $\mathrm{w}$ ślesińskim zakładzie pierzarskim.

Drugą strategią stosowaną w popularyzowaniu regionalnych/lokalnych kuchni jest nadawanie potrawom „szczególnych” nazw. Zabieg ten $z$ jednej strony powoduje, że turysta/klient restauracji zwraca uwagę na potrawę/produkt, zaś $z$ drugiej strony sprawia, że to „nowe” jedzenie nie zostanie przez niego odebrane jako niesmaczne lub niejadalne (Long 2015, s. 443). Kuchnia ochweśnicka już w swojej nazwie wywołuje zainteresowanie, gdyż nie kojarzy się z miejscem, regionem ani profesją. $Z$ drugiej strony, nie przywodzi też na myśl żadnych skojarzeń, które mogłyby zniechęcać do konsumpcji. Dodatkowo w zbiorze potraw tej kuchni znalazły się dania o zagadkowych nazwach, takie jak obsypunka, prażuchy, pyrczok, owijonki i gęsie pipki, co powoduje, że odbierane są one jako niecodzienne i egzotyczne. Natomiast niestosowanie tych nazw we współczesnym języku wskazuje dodatkowo na ich odniesienia do przeszłości. Dodanie zaś określenia ochweśnicki bądź ślesiński podkreśla związek jedzenia z miejscem jego pochodzenia.

Trzecią strategię stanowi „opowieść”, która może wyjaśniać skład potrawy, tłumaczyć jej związki z miejscem i przeszłością czy też uczy interpretować znaczenia przypisane kulturowo jedzeniu (Long 2015, s. 443-444). Strategia ta jest

2 Oberża to, zwłaszcza dawniej, dom na wsi lub przy uczęszczanej drodze, w którym można coś zjeść i wypić za opłatą, czasem też przenocować (https://dobryslownik.pl/slowo/ober\%C5\%BCa /32348/\#znaczenie-20101). 
najpowszechniej stosowana. To w oparciu o nią powstają kuchnie narodowe, pradawne potrawy związane albo $z$ ważna osobą (np. truskawki a lá Romanow), albo z miejscem (np. panforte z Sieny). W przypadku kuchni ochweśnickiej opowieść sięga nie do końca sprecyzowanego czasu w przeszłości³, kiedy handel gęśmi w okolicach Ślesina był opłacalny. Zgodnie z nią handlarze gęśmi, hodowcy drobiu oraz mieszkańcy Ślesina bądź okolicznych wsi wypracowali swoistą kuchnię o prostych, acz pożywnych daniach. W kuchni tej oprócz historycznych związków z przeszłością podkreślany jest jej wiejski charakter (książka ze spisem receptur kuchni ochweśnickiej wydana została pod nazwą „Kuchnia wiejska”).

Dostosowanie menu do klienta to sposób na upowszechnianie kuchni etnicznych, których pewne dania nie znalazłyby odbiorców (w ilości pozwalającej na utrzymanie lokalu gastronomicznego) w innej społeczności. W tym celu dobiera się receptury, tak aby zachowały swój egzotyczny charakter, a zarazem były podobne do dań jedzonych przez daną społeczność (Long 2015, s. 444). Ten zabieg stosowany jest sporadycznie w przypadku kuchni lokalnych, choć nie oznacza to, że nie jest wykorzystywany. Polega on na szczególnym doborze menu. Muszą się w nim znaleźć symboliczne dla danej kuchni potrawy, aby mogła być rozpoznawalna. W przypadku kuchni ochweśnickiej takimi daniami, które pozwalają się jej wyróżnić, są: obsypunka, pyrczok i czernina z owijonkami.

Ostatnia metoda na upowszechnienie „nowej” kuchni polega na dostosowaniu dań do gustów kulinarnych jej odbiorców (Long 2015, s. 445). W kuchni ochweśnickiej polega to na uwspółcześnianiu potraw, które obfitują w dodatki warzywne i owocowe. Sposoby na przygotowanie pieczonej gęsi są tak różnorodne, że zadowolą nawet szukających nowych doznań kulinarnych foodi.

\section{Jedzenie w kulturze ludowej}

Kuchnia ochweśnicka nie jest kuchnią regionalną rozumianą jako tradycyjna, codzienna bądź domowa kuchnia, którą charakteryzuje różnorodność regionalna. Nie jest też kuchnią będącą w opozycji do kuchni propagowanej przez podmioty przygotowujące jedzenie w celach komercyjnych ani też kuchnią ukształtowaną przez informacje zaczerpnięte $z$ nauk zajmujących się żywnością i żywieniem. Kształt kuchni regionalnej był odbiciem dostępnych dla społeczności produktów żywnościowych oraz jej religii. Związek kuchni z religią mógł mieć charakter zarówno pozytywny, przejawiający się różnego rodzaju potrawami świątecznymi, jak i negatywny, w postaci zakazów pokarmowych, najczęściej związanych z okresami postu bądź z tabu pokarmowym. Dostępność produktów natomiast wyznaczała granice kulinarnej kreatywności danej społeczności (Yoder 1972, s. 325-350). Analizując potrawy kuchni ochweśnickiej, trudno nie zauważyć, że podstawowym jej składnikiem jest gęsina, mimo że w okolicach Ślesina w większości gospodarstw zaniechano hodowli tych ptaków. Gęsina nie jest też mięsem

Zjawisko to jest powszechnie znane jako tworzenie tradycji wynalezionych, w ramach których odwołanie się do przeszłości bliżej nieokreślonej jest sposobem na uwiarygodnienie tworzonej tradycji. Więcej na ten temat w opracowaniu Hobsbawm i Ranger T. (2008). 
tanim 4 , co mogłoby czynić ją powszechnie dostępną. Gęsina jest dobrem rzadkim i drogim oraz ma swoją lokalną opowieść, czyli jest doskonałym produktem do jedzenia związanego ze szczególną okazją, taką jak święta religijne, ważne uroczystości rodzinne, ale również wyjazdy o charakterze turystycznym. Wydaje się, że potrawy z gęsiny, które wcale nie musiały być popularne wśród hodowców i handlarzy gęśmi, z dużym prawdopodobieństwem na wsi początku XX w. były świątecznym daniem. Zostały jako takie zapamiętane i w momencie, kiedy koła gospodyń wiejskich zostały zobligowane do wskazania dawnych, tradycyjnych dań, ich wspomnienie zostało ponownie przywołane. Zapotrzebowanie na receptury oraz zmieniające się gusta kulinarne sprawiły, że gęś w kuchni ochweśnickiej przygotowywana jest na wiele sposobów. Potrawy z ziemniaków, takie jak pyrczok i obsypunka, są reminiscencją czasów, gdy ziemniaki stanowiły podstawę diety mieszkańców wsi. Powrót do lokalnej kuchni, nawet jeśli tylko restauracyjnej bądź kiermaszowej, zawdzięczają swej niecodziennej nazwie. Zatem bardziej należałoby rozpatrywać tę kuchnię $\mathrm{w}$ kategoriach produktu turystycznego oraz narzędzia promującego region niż kuchni regionalnej, która stanowi historię społeczności zakodowaną w jedzeniu (co nie oznacza, że nie jest zbudowana $z$ „okruchów" pamięci kulinarnej mieszkańców okolic Ślesina). Kuchnia ochweśnicka nie ma dań, które byłyby upamiętnieniem jakichś wydarzeń z życia społeczności, nie obfituje $\mathrm{w}$ produkty powszechnie dostępne $\mathrm{w}$ regionie (gęsina do takich nie należy), za to mówi o przeszłości w sposób wyrywkowy, a wspomnienia potraw z dawnych lat mieszają się ze współczesnymi ich interpretacjami, jak też z zupełnie nowymi recepturami, które sprawiają, że staje się ona bogatsza, może bardziej dostosowana do oczekiwań współczesnego odbiorcy.

\section{Wspieranie produktów tradycyjnych/regionalnych}

Przełom XX i XXI w. to czas, kiedy silnie wzrasta zainteresowanie jedzeniem w jego niebiologicznym wymiarze. Jedzenie zaczyna być istotną częścią kultury, a niekiedy recenzentem zachowań ludzkich, co znalazło odzwierciedlenie w opiniach, np.: jedząc codziennie obiad przy wspólnym stole zapewniamy szczęście naszej rodzinie, rezygnując z jedzenia mięsa, sprawimy, że świat nie będzie skażony przemocą (Glassner 2007, s. 9-13), egzotyczne kraje poznajemy poprzez doświadczanie ich kultury kulinarnej, wolny czas spędzamy w restauracjach, które mogą być też celem wypraw turystycznych. Pojawia się świadomość, że dla Ziemi i dla ludzi ją zamieszkujących korzystne jest nabywanie jedzenia, które powstaje w najbliższym otoczeniu, gdzie konsument zna jego producenta (w literaturze przedmiotu jest to tzw. bliskość społeczna). Powstają liczne publikacje (Pretty i in. 2005, Coley i in. 2011, Tundys 2015, Bloemhof $i$ in. 2017, Ludwik 2018), których głównym przedmiotem zainteresowania jest produkt lokalny, już w swej lokalności zawierający przekaz, że jest bardziej naturalny (istotnie często produkty

4 Obecnie często cena decyduje o dostępności produktu spożywczego. Więcej na ten temat w opracowaniu Chudzyńskiej (2014). 
ekologiczne są dystrybuowane $z$ pominięciem pośredników albo w specjalistycznych sklepach, których właściciel zna producentów), typowy dla regionu i często tradycyjny. Regionalność i tradycyjność żywności staje się wartością, którą Polacy cenią głównie za smak i zapach (Grębowiec 2017, s. 65-80). Do ochrony ich autentyczności i jakości służy unijny system certyfikowania produktów spożywczych. Jednak uzyskanie europejskiego certyfikatu dla produktu tradycyjnego bądź regionalnego jest procesem dość długotrwałym i wymagającym współpracy kilku lokalnych producentów tego produktu podczas składania wniosku o jego rejestrację. Znacznie łatwiej uzyskać wpisanie produktu/potrawy na Listę Produktów Tradycyjnych prowadzoną przez Ministerstwo Rolnictwa i Rozwoju Wsi. Lista ta ma za zadanie uchronienie przed zapomnieniem tradycyjnych/regionalnych produktów/potraw. To właśnie na niej odszukać można w zakładce województwa wielkopolskiego ziemniaczane potrawy kuchni ochweśnickiej, takie jak: szare kluski (wpisane na listę 11.05.2007), plyndze (17.12.2009), bambrzok (3.06.2013), pyrczok (25.10.2019) (https://www.gov.pl/web/rolnictwo/woj-wielkopolskie). Daty wpisywania potraw na wspomnianą listę wskazuja, że działania związane $z$ promocją regionalnych potraw nie zostały zaniechane. Niestety $w$ ich opisie nie ma wzmianki o związku z kuchnią ochweśnicką, zostają zaliczone do dużego zbioru potraw typowych dla Wielkopolski. W tym przypadku może nie mieć to dużego znaczenia, gdyż rozpoznawalność produktów wpisanych na Listę Produktów Tradycyjnych oraz certyfikowanych unijnymi oznaczeniami w polskim społeczeństwie jest bardzo mała (Sieczko 2014, s. 397-406). Jednak dużo wskazuje na to, że rynek produktów regionalnych jest jeszcze na początku swojego rozwoju, konsumenci potrzebują produktów $z$ historią, które są elementem szerszego kontekstu kulturowego. Poznając nowe miejsce, chcą poznać i jego jedzenie. Doskonałym miejscem kulinarnej edukacji od lat są festyny i targi rolnicze, gdyż to dzięki nim wiedza na temat lokalnych kuchni staje się coraz większa, a też i lokalne kuchnie stają się bardziej dostosowane do swoich odbiorców. Pomysł na kuchnię ochweśnicką doskonale wkomponowuje się w oczekiwania współczesnego konsumenta, ponieważ pozornie oferuje nieco swojskiej egzotyki i naturalności, choć przy bliższym poznaniu bardzo traci.

\section{Podsumowanie}

Kuchnia ochweśnicka ma swoją opowieść, ma potrawy o osobliwych nazwach, które kryją dania prostej kuchni chłopskiej połowy XX w., ma też swój wyróżnik w postaci gęsiny (choć wyróżnik ten nie spełnia swojego zadania, ponieważ gęsina od lat promowana jest jako produkt województwa kujawsko-pomorskiego, a co gorsza - dodatkowo jako ogólnopolski specjał na Święto Niepodległości). Ma również wszystkie cechy „nowego” jedzenia, opisane przez Lucy Long, które umożliwiają jego akceptację przez konsumentów, a zarazem wywołują zainteresowanie. Zatem kuchnia ta powinna być skutecznym narzędziem promującym swój region. Jednak wyniki niniejszego opracowania temu przeczą. Znacząca większość opinii na temat skuteczności metod zastosowanych przez podmioty 
zaangażowane $\mathrm{w}$ promocję kuchni ochwaśnickiej jest negatywna. Jedną z zasadniczych przyczyn tego zjawiska może być brak dbałości o smak oferowanych potraw oraz ich pospolity charakter. W produkcie gastronomicznym jego rdzeń stanowi „nowy smak” (Stasiak 2016, s. 11-12), jest to element niezbędny, którego w oczekiwaniach turysty nie może zabraknąć. Jednak smak w badaniach jest elementem trudnym, gdyż słabo mierzalnym.

Natomiast co do oceny drugiego czynnika, to pomimo, że pieczony w blasze placek ziemniaczany, zwany koło Ślesina pyrczokiem, ma swoje różne regionalne wersje, np. borowiacką (Bory Tucholskie), w postaci szandaru, podlaską jako babka ziemniaczana czy kurpiowską jako rejbak, to analizując w ten sposób kolejne potrawy kuchni ochweśnickiej, można zauważyć, że zasadniczo kuchnia ta nie ma potrawy, która byłaby unikatowa bądź „dziwna”. Odnosząc się do wypowiedzi dyrektora ślesińskiego ośrodka kultury, że „kuchnia ochweśnicka powstała z niczego", można stwierdzić, że zazwyczaj z niczego powstaje nic, nie zaś coś. Yoder (1972, s. 350) swój artykuł na temat kuchni regionalnych zakończył parafrazą powszechnie znanego powiedzenia o religii, że: „Każdy naród, każda kultura i każde pokolenie tworzy taką kuchnię na jaką zasługuje”. Właściwsze byłoby stwierdzenie, że ma taką kuchnię, na jaką społeczność stać, do jakich produktów ma dostęp, jakie potrawy tej społeczności smakują bądź jaką kuchnię uważa za zdrową i naturalną. Jednak warto zauważyć, że kuchnia ochweśnicka to kuchnia festynów i restauracji (tak przynajmniej zakładano w realizowanym projekcie unijnym) i nie stanowi odbicia zwyczajów żywieniowych społeczności, a jedynie wizję kuchni tradycyjnej i regionalnej wybranych osób z tej społeczności. Mimo to proces twórczy trwa, więc może wśród działań mających na celu promowanie lokalnej kuchni pojawią się nowe, ciekawe, a przede wszystkim smaczne, pomysły na promocję regionu, w którym onegdaj kwitł handel gęśmi.

\section{Literatura}

Augustyniak D. 2020. Gastronomia i turystyka - od kuchni ochweśnickiej do Sanktuarium Matki Bożej w Licheniu. Praca licencjacka pod kierunkiem dr I. Chudzyńskiej. Turystyka i Rekreacja, Wyższa Szkoła Gospodarki w Bydgoszczy.

Bender A.E. 1980. Człowiek i żywność. Tłum. T. Rożniatowski. Państwowe Wydawnictwo Naukowe, Warszawa.

Bloemhof J.M., Soysal M. 2017. Sustainable food supply chain design. [W:] Y. Bouchery, C.J. Corbett, J.C. Fransoo, T. Tan (red.), Sustainable supply chains. Springer, Amsterdam, s. 395-412.

Boroński B., Chmielewski M. (br.). Kuchnia wiejska. Miejsko-Gminny Ośrodek Kultury w Ślesinie, Ślesin.

Budzińska A., Fijałkowska E., Jakubowska E., Łakomiak H., Fijałkowski J., Fijałkowski S. 2013. Ślesin. Naprawdę warto. Przewodnik turystyczny po mieście i gminie. Towarzystwo Społeczno-Gospodarcze „Dwa Mosty”, Ślesin.

Chudzyńska I. 2014. Instytucjonalne kształtowanie tradycyjnej kuchni na terenie Krajny, na podstawie badań prowadzonych w gminie Sicienko. [W:] A.W. Brzezińska, J. Schmidt (red.), Regiony i regionalizmy w Europie. Wrocław, s. 255-264.

5 W latach 30. XX w. w Wielkiej Brytanii przeprowadzono kampanię promującą picie soku pomarańczowego, niestety mimo zainwestowanych w to przedsięwzięcie dużych pieniędzy nie udało się Brytyjczyków nakłonić do powszechnego picia tego soku, jak miało to miejsce w Stanach Zjednoczonych Ameryki (Bender 1980, s. 105-106). 
Coley D., Howard M., Winter M. 2011. Food miles: time for a re-think? British Food Journal, 113(7): 919-934.

Durydiwka M. 2013. Turystyka kulinarna - nowy (?) trend w turystyce kulturowej. Prace i Studia Geograficzne, 52: 9-30.

Glassner B. 2007. The gospel of food. Harper Collins Publishers, New York.

Grębowiec M. 2017. Produkty regionalne i tradycyjne jako element budowania konkurencyjnej oferty produktów żywnościowych w Polsce i innych krajach Europy. Zeszyty Naukowe SGGW w Warszawie, 17(32): 65-80.

Hobsbawm E., Ranger T. 2008. Tradycja wynaleziona. Tłum. M. Godyń, F. Godyń. Wydawnictwo Uniwesytetu Jagiellońskiego, Kraków.

Long L.M. 2015. Culinary tourism: a folkloristic perspective on eating and otherness. [W:] L.M. Long (red.), The food and folklore reader. Bloomsbury Academic, London-New York, s. 437-448.

Pretty J.N., Ball A.S., Lang T., Morison J.I.L. 2005. Farm cost and food miles: an assessment of the full cost of the UK weekly food basket. Food Policy, 30(1): 1-19.

Sieczko A. 2014. Produkty regionalne i tradycyjne w promocji regionów. Turystyka i Rozwój Regionalny, 2: 79-89.

Stasiak A. 2016. Turystyka kulinarna w gospodarce doświadczeń. Turystyka Kulturowa, 5: 6-26.

Tundys B. 2015. Krótkie łańcuchy dostaw produktów spożywczych (SFSC) - ujęcie teoretyczne i praktyczne. Studia Ekonomiczne, 249: 49-110.

Yoder D. 1972. Folk cookery. [W:] R.M. Dorson (red.), Folklor and folklife: an introduction. University of Chicago Press, Chicago, s. 325-350.

\title{
Strony internetowe
}

http://gminaslesin.futurehost.pl/o-gminie/historia (dostęp: 27.08.2020)

https://pl.wikipedia.org/wiki/Pa\%C5\%82ac_w_Lisewie (dostęp: 26.08.2020)

https://kieruneknadzis.blogspot.com/2018/08/tam-gdzie-podkuwano-gesi-slesin.html (dostęp: 27.08.2020)

http://idziemy.pl/spoleczenstwo/kolebka-ochwesnikow (dostęp: 28.08.2020)

http://docplayer.pl/7464361-Kuchnia-ochwesnicka-produktem-markowym-gminy-slesin.html (dostęp: 28.08.2020)

http://www.oberzaslesin.pl/index.html (dostęp: 28.08.2020)

http://faow.org.pl/wpcontent/uploads/2018/12/2Ciekawe_Inicjatywy_K\%C5\%81Z\%CC\%87_Ekspertyza_Ludwik (dostęp: 10.09.2020)

https://www.gov.pl/web/rolnictwo/woj-wielkopolskie (dostęp: 10.09.2020)

\section{Ochweśnica cuisine the promoting tool of the region}

\begin{abstract}
Modern food has taken on a new, broader dimension. It is more than a way to satisfy hunger, to express one's social position, or to define one's national or regional identity: modern food is conscious food, it is a way to express one's worldview, part of modern ethics. Food is also an excellent tool to promote a city, a region or a small area, which often corresponds to a specific local government unit. Such an example is the Ochweśnica cuisine which encompasses two communes of Ślesin and Skulsk in Wielkopolska. The aim of the study is to analyze issues related to regional cuisine as a tool for effective promotion of the region, based on the example of the Ochweśnica cuisine. The research method applied in this study is closely related to its objectives. The analysis of existing data - the so-called desk research - was used along with the five strategies for promoting ethnic/local cuisine developed by Lucy M. Long. As a result, it was established that the dishes of the Ochweśnica cuisine, even though they have all the features of "new" food described by L.M. Long, do not arouse the tourists' interest. The reasons for this phenomenon can be found in the lack of innovation of the dishes of this cuisine. The gastronomic product offered to tourists should contain the "new taste", which was apparently missing in the Ochweśnica cuisine.
\end{abstract}

Key words: culinary tourism, culinary heritage, regional development strategy, Ochweśnica cuisine 